\author{
MARYNA FROTVEIT, \\ Vasyl' Stus Donetsk National University (Vinnytsia, Ukraine) \\ e-mail:mn.kasianova@gmail.com,ORCID 0000-0002-4681-1664
}

\title{
FORMATION AND IMPLEMENTATION OF THE MIGRATION LEGISLATION OF UKRAINIAN CITIZENS TO BELARUS, MOLDOVA AND RUSSIA (1991-2013)
}

\begin{abstract}
The article reflects the rulemaking and legislative regulation of the migration sphere in the region, based on a common documentary basis, which is the basis of the national legislation of the studied countries - the legal provisions of the Soviet period. Another source of international law is the common international norms developed within the framework of universal and specific interstate structures (UN, IOM, ILO, etc.). The process of formation and improvement of migration legislation in the Republic of Belarus, the Republic of Moldova, the Russian Federation and Ukraine continued throughout the study period. Its basic elements include the creation of a regulatory framework for general issues that indirectly dealt with migration issues and address specific issues of a purely migration area. Its results were in accordance with general norms and democratic principles. The article focuses on the migration concepts of each of the countries studied. It is concluded that the nature and magnitude of the migration movement of Ukrainians within the studied region are distinguished by the specificity of the respective migration space. It is based on strong cultural and historical ties between actors and is reinforced by the migration laws of Belarus, Moldova, Russia and Ukraine.
\end{abstract}

Key words: migration; migration policy; migration legislation; migration processes.

\section{Introduction}

Migration legislation directly reflects the relevant policy concepts and strategies adopted in the country regarding the phenomenon of migration. It aims to regulate the implementation in practice of specific migration policies of the state actor. In this context, it can be considered as a subjective continuation of the activities of state bodies. On the other hand, it includes a whole set of bills that in one way or another affect the phenomena of migration, its specific forms and manifestations (labor migration and the problem of employment for foreigners, forced migration and the issue of refugee status). In this context, the specificity of the current migration process poses an objective challenge for the state, which the latter must respond to in the form of rulemaking. Whatever the goals and objectives of the country, its policy strategy - it should in any case form the legislative base on a specific list of topical issues (eg border crossing, employment of foreigners, etc.), most of which are directly or indirectly related to the migration problem. Migration, as a social phenomenon and social phenomenon, requires specific regulation by state authorities and government, a regulatory system that will ensure the implementation of migration policy adopted in the country. In the absence thereof, it can be transformed into an unregulated social system. The proposed regulation of this phenomenon is presented in several forms - in the form of rules of international law, enshrined in the documents of universal and specific organizations, in the format of bilateral and multilateral interstate agreements and at the level of national legislation on migration issues.

Studies of specialists from various fields of knowledge make it possible to understand the conditions under which migration processes take place, to evaluate the positions of individual countries regarding migration and compare them with generally accepted international standards.
Linguists, for example, examine the linguistic media and media strategies that influence the perception of migrants by the local population (Blakar, 1979; Ruz, 2015; Komarova, 2019). The historians D. Hoerder, (2002) devote their work to the analysis of the causes of knowledge and the history of the development of "migration nodes". F. Shenk (2001; 2019). A very detailed history of the formation of migration laws in Europe is also considered in (Bessa Vilela, Brezovnik, 2018; Sredanovic; Stadlmair, 2018). Critical issues that are ambiguously interpreted in European migration legislation are raised by I. Kuznetsova, J. (2019), I. Carles-Berkowitz (2015) and R. Hansen (1999).

Despite the variety of areas of study of migration processes (economic, demographic, sociological, geographical, historical, psychological, political, etc.), researching them within their own subject fields at macro, meso or micro levels, studying political, legal and economic aspects migration, we come to the conclusion that there is a constant exchange of ideas and concepts between individual scientific schools and approaches. Historians rely on theories formulated by sociologists, demographers use the position of research by economists and political scientists, jurisprudence is incorporated into all social and historical studies of migration processes and more (Castles, Miller, 1993: 420; Kozykina, 2010: 82).

At the same time, an important link in the scientific research of migration issues is national policy and the forms of its regulation in countries that are close to the local conflict zone, as, for example, happened in Ukraine in 2014.

The purpose of this study is to analyze a set of regulations of migration legislation of individual countries of Eastern Europe (Ukraine, Russian Federation, Republic of Belarus, Republic of Moldova) and to conclude on their common basis in the form of documents of the Soviet period and provisions of international law. 


\section{Methods}

Research methodology (approaches, principles, methods), in addition to conceptual backgrounds and empirical basis, is determined by its interdisciplinary nature (Buzan, Waever, DeWilde, 1998: 241). The article is based on the application of a wide range of general scientific, political, sociological methods and approaches. Thus, the comparative-historical method helps to compare the political and legal principles of regulation of migration of citizens in the region in the framework of compliance with international law and the formation of national legal bases of the post-Soviet states. This method may be useful when studying different groups of sources. For example, regulations and sources of personal identity cover the same events in different ways, and the use of the information comparison method will help you come to an objective conclusion. The use of the problem-chronological method made it possible to identify the most important external and internal factors that influenced the political and systemic transformation of the studied region, and to determine at various stages the role of the state in regulating migration flows and processes. Following the problemchronological method does not work without analytical and logical methods. Thanks to their use, the material is presented in a clear sequence and logical completeness.

\section{Results and Discussion}

The rulemaking and legislative regulation of the migration sphere in the region is based on a common documentary basis, which is the basis of the national legislation of the studied countries - the legal provisions of the Soviet period. Another source of migration law is the generally accepted international standards developed within the framework of universal and specific interstate structures (UN, IOM, ILO, etc.).

The process of formation and improvement of migration legislation in the Republic of Belarus, the Republic of Moldova, the Russian Federation and Ukraine continued throughout the study period. Its main elements include the creation of a regulatory framework for common issues that indirectly address migration issues and address specific problems of a purely migration area. Its results are in line with general norms and democratic principles. However, their practical implementation remains problematic in the context of corruption in the governments of the countries studied and the ambiguous attitude of societies towards particular categories of migrants.

From a political point of view, the migration concepts of each of the countries studied had their own specific features. Only the Republic of Belarus did not invest in them the proper content, focusing on the economic effect of intensifying subregional processes of population displacement (expressed in encouraging skilled personnel from the countries of the former Soviet Union to contribute to the development of the republic). Moldova has tried to solve the radical problem of labor shortages caused by the fact that the citizens of this country have been actively traveling abroad. The Russian Federation viewed migration as an important element of its own regional policy, an instrument of pressure on neighboring countries, and a method of drawing them into its area of influence. It is in this context - in terms of maintaining its global presence in Ukrainian political discourse - that Russian politicians have emphasized the positive effects of migration exchanges between the Russian Federation and Ukraine. Thus, it is one of the elements of the Kremlin's global aggressive strategy aimed at the imperialist domination of Russia in the post-Soviet space.

The system of international migration law began to emerge after the Second World War, when the newly formed United Nations made the necessary efforts to formalize this area. Its foundations and basic provisions are set out in the UN Charter $(1945)^{1}$, the Universal Declaration of Human Rights $(1948)^{2}$, the Convention for the Protection of Human Rights and Fundamental Freedoms $(1950)^{3}$, the Convention on the Status Refugees $(1951)^{4}$, International Convention for the Protection of the Rights of All Migrant Workers and Members of Their Families $(1990)^{5}$. Each of these documents is extremely important. For example, today there is no doubt that the democratization of public life in all countries of the world determines the freedom to choose a person's place of residence regardless of place of birth and nationality. For the first time, this right was enshrined in Article 13 of the Universal Declaration of Human Rights, which stated that "everyone has the right to move freely and to choose his place of residence within each State; Everyone has the right to leave any country, including his own, and to return to his own country"6.

They are designed to foster economic stability and equal opportunity for everyone, regardless of race, creed or gender, to exercise their right to material well-being. Achieving the main goal of these international organizations requires proper inter-state cooperation, which is why the ILO and IOM's core documents clearly state the desire to cooperate with the governments of the world, which are responsible for ensuring the material well-being of their citizens. In view of this, it is these intergovernmental structures that support international migration law, facilitate the public debate on migration policy and develop recommendations aimed at protecting the rights of migrants. The ILO and IOM create the conditions for the adoption by the countries of the world of such programs and regulations, which are primarily aimed at solving the most pressing problems for people of work - ensuring their work and proper life, health and education systems, rest, etc.

The rights of migrants are primarily enshrined in ILO Convention 97 on Migrant Workers ${ }^{7}$, which concerns the most widespread category of migrants in the world today. Article 11 of this document defines a "migrant worker" as a person who migrates from one country to another with the intention of obtaining a job differently than at his own expense. A comprehensive definition includes any person who is recognized by law as a migrant worker. The member countries of the ILO for which this Convention is in force

${ }^{1}$ Статут Організації Об'єднаних Націй (Charter of the United Nations). Retrieved from http://zakon0.rada.gov.ua/laws/show/ 995_01

2 Загальна декларація прав людини (Zahalna deklaratsiia prav liudyny). Retrieved from http://zakon0.rada.gov.ua/laws/show/ 995_015 (data zvernennia: 28.08.2017)

${ }^{3}$ Конвенція про захист прав людини і основоположних свобод (Konventsiia pro zakhyst prav liudyny i osnovopolozhnykh svobod). Retrieved from http://zakon3.rada.gov.ua/laws/show/ 995004 (data zvernennia: 28.08.2017)

${ }^{4}$ Конвенція ООН про статус біженця (Konventsiia OON pro status bizhentsia). Retrieved from http://zakon3.rada.gov.ua/laws/ show/995_011 (data zvernennia: 28.08.2017)

${ }^{5}$ (UN International Convention on the Protection of the Rights of All Migrant Workers and Members of Their Families No. 995203 of December 18, 1990). Retrieved from http://zakon3.rada.gov.ua/ laws/show/995 j91 (date of death: 08/28/2017)

6 Загальна декларація прав людини (Zahalna deklaratsiia prav liudyny). Retrieved from http://zakon0.rada.gov.ua/laws/show/ 995_015 (data zvernennia: 28.08.2017)

${ }^{7}$ Конвенція МОП № 97 про працівників-мігрантів від 1 ліпня 1949 p. (Pro pratsivnykiv-mihrantiv vid 1 lypnia 1949 r.). Retrieved from http://zakon.rada.gov.ua/laws/show/993 159 (data zvernennia: 28.08.2017) 
shall, at the first request, make available to the International Labor Office and any other member of the organization information on the policies and legislation of their country in the field of emigration and immigration; information on specific provisions applicable to migration for employment purposes, as well as the working conditions and residence of migrant workers (Article 1 of the current document). The Convention focuses on the definition of the rights of migrants and their protection mechanisms. In accordance with Articles 5 and 6 , each member of the organization undertakes to provide migrant workers and their families with the necessary medical care and hygiene conditions; act on them without discrimination based on nationality, race, religion or gender; to provide migrants with no less favorable conditions than their own citizens for living and working conditions (wages, working hours, social security, etc.). Migrants should be provided with housing. They are also eligible for union membership and may participate in collective agreements. Services provided to migrants by public employment services should be free of charge. Equality in the application of the principles of respect for fundamental rights and freedoms for migrants is separately ensured by ILO Conventions No. 100 "On Equal Remuneration of Men and Women for Work of Equal Value" $(1951)^{8}$, No. 111 "On Discrimination in Labor and Employment" $(1958)^{9}$, No $143^{\prime \prime}$ On the abuse of migration and on ensuring equal opportunities and equal treatment for migrant workers" $(1975)^{10}$.

When referring to the application of the principles and norms established by IOM and ILO with regard to the migration field in the Eastern Europe region, it is worth considering separately how far they have been adopted and implemented by regional states. First, let's analyze the example of Ukraine. It has been a member of the International Organization for Migration since 2002 and has the appropriate status and rights. The representative office of this institution was opened in Kyiv in 1996. Its activities are primarily aimed at promoting awareness of the opportunities and problems of migration in the Ukrainian context, combating trafficking in human beings, assisting the Government of Ukraine in improving its system of migration management, and developing a health policy that addresses migrants. The IOM Office is involved in exploring and promoting the creation of legal channels of employment for Ukrainian migrant workers, harnessing the potential of migrant development and integration, promoting cultural diversity and combating xenophobia and intolerance.

With regard to the argument of such neglect, some documents from the Ukrainian side can lead to a discussion of the possible possibility of ratification of ILO

\footnotetext{
8 Конвенція МОП № 100 Про рівну винагороду чоловіків і жінок за працю рівної цінності (Konventsiia MOP № 100 Pro rivnu vynahorodu cholovikiv i zhinok za pratsiu rivnoi tsinnosti). Retrieved from http://www.ilo.org/dyn/normlex/en/f?p =NORMLEXPUB:12100:0::NO:12100:P12100_INSTRUMENT_ID:312245:NO (data zvernennia: 28.08.2017)

9 Конвенція МОП № 111 Про дискримінацію в галузі праці (Konventsiia MOP № 111 Pro dyskryminatsiiu $v$ haluzi pratsi y zaniat). Retrieved from http://www.ilo.org/dyn/normlex/en/ $f ? p=N O R M L E X P U B: 12100: 0:: N O: 12100: P 12100$ INSTRUMENTID:312256:NO (data zvernennia: 28.08.2017)

10 Конвенція МОП № 143 Про зловживання в галузі міграції про забезпечення працівникам - мігрантам рівних можливостей і рівного ставлення від 24 серпня 1975 р. (Konventsiia MOP № 143 Pro zlovzhyvannia v haluzi mihratsii i pro zabezpechennia pratsivnykam-mihrantam rivnykh mozhlyvostei i rivnoho stavlennia vid 24 servnia 1975 r.). Retrieved from http://zakon.rada.gov.ua/laws/show/993_163 (data zvernennia: 28.08.2017)
}

Convention No. 143 and the UN Convention on the Protection of the Rights of All Migrant Workers and Members of Their Families, carried out by the Ukrainian Government in 2004. As an argument against joining the documents, the domestic Ministry of Labor and Social Policy cited the fact that most countries where Ukrainian wage earners work also avoid signing the said conventions. In our view, this approach to the question is ambiguous. The fact that the documents mentioned above is that their effect also extends to illegal labor migrants. Given that today and in the near future, the number of Ukrainians who work illegally abroad will remain far higher than the number of foreigners in a similar position in Ukraine, it should be recognized as exaggerated fears of government officials about the negative impact on the Ukrainian labor market. conventions. In our opinion, the consequences of their ratification by Ukraine should be analyzed in more detail, determining whether in this case additional mechanisms will be provided to protect the rights of Ukrainian workers abroad. At the same time, it is worth assessing how serious the threat of an influx of undocumented migrants from countries with a lower standard of living is.

The partnership is being activated in the following areas:

- improvement of the system of management of arrangement of checkpoints across the state border of the Russian Federation;

- the fight against human trafficking in the Russian Federation;

- development and implementation of state programs in the field of labor migration management;

- providing a wide range of services for migrant workers and their families;

- implementing measures to increase social tolerance for migrant workers;

- Assistance in voluntary return to countries of origin, etc.

However, in practice, the matter has not moved from the dead - the issue of Russian Federation membership in the International Organization for Migration remains open.

In addition to the above-mentioned institutions, regional integration associations are contributing to the formulation of common rules on the treatment of migrants in the territory of the region - their documents on relevant issues include the Commonwealth of Independent States (CIS) Convention on Human Rights and Fundamental Freedoms (1995) $)^{11}$. In characterizing the situation in the post-Soviet space, which directly affects the legal status of migrant workers - citizens of Ukraine in the Russian Federation, Belarus and the Republic of Moldova, other regional initiatives aimed at improving the legal framework should also be addressed. This is precisely what the interstate treaty, such as the Agreement on Cooperation in the Field of Labor Migration and Social Protection of Migrant Workers $^{12}$, which was adopted within the CIS on April 15,

\footnotetext{
11 Конвенція Співдружності незалежних держав про права та основні свободи людини (Konventsiia Spivdruzhnosti Nezalezhnykh Derzhav pro prava ta osnovni svobody liudyny). Retrieved from http://zakon5.rada.gov.ua/laws/ show/997_070 (data zvernennia: 28.08.2017)

12 Соглашение о сотрудничестве в областы трудовой миграции и социальной защиты трудящихся-мигрантов и социальной защиты трудящихся мигрантов от 15 апреля 1994 г. (Soglasheniye o sotrudnichestve $v$ oblasti trudovoy migratsii $i$ sotsialnoy zashchity trudyashchikhsya-migrantov ot 15 aprelya 1994 g.). Retrieved from http://ialm.ru/pages/71/id127.html (data zvernennya: 28.08.2017)
} 
1994 and ratified by Ukraine on July 11, 1995, is intended. the worker is subject to the legislation of the recipient country and, in essence, has the same rights, obligations, social security and social security (other than pension) as nationals of the host country. Also, this agreement provides for mutual recognition by the parties of the length of service, documents on education and qualification necessary for carrying out work activities. Accordingly, the conditions of work and social insurance of the migrant worker are governed by the law of the country of employment. On 25 November 2005, the agreement was further enhanced by a special Protocol amending the document ${ }^{13}$. It was aimed at simplifying the order of employment for border workers - that is, those working in the territory of one of the neighboring states while permanently resident in the territory of the other. In 2008 , a further attempt was made to improve the legal status of migrant workers in CIS countries through the adoption of the Convention on the Legal Status of Migrant Workers and Members of Their Families of the Commonwealth of Independent States ${ }^{14}$. The draft document clearly outlined the different categories of migrant workers, established their status, outlined their rights and responsibilities. However, this convention did not enter into force.

This uncertain situation has developed despite the fact that migration issues are the sphere of activity of a number of state bodies of Ukraine. Managing the migration process in the country during the main part of the study period was within the competence of the State Department for $\mathrm{Na}$ tionalities and Migration, which functions within the Ministry of Justice of Ukraine. He has collaborated with other government agencies, notably the Ministry of Labor and Social Policy, the Ministry of the Interior, the Ministry of Health, the Ministry of Foreign Affairs and the State Committee for State Border Protection. Each of these structures is responsible for a particular area of work. The Ministry of Foreign Affairs of Ukraine performs the tasks in the field of legal migration management. Its structures are responsible for organizing visas, consular work, ensuring the protection of the rights of Ukrainians living abroad. The Ministry of Labor and Social Policy was responsible for addressing issues related to labor migration. The State Border Guard Service of Ukraine opposes illegal migration and registers foreign nationals. The Ministry of Health of Ukraine, which oversees the state of health and epidemiology, and the Ministry of Justice of Ukraine are also competent in this area.

Analyzing the institutional support of the work of the Ukrainian authorities in the migration sphere, it should be noted that the control over compliance with international treaties in the field of regulation of migration processes until 2011 was practically not exercised due to the absence of a separate State Migration Service of Ukraine. The subjects of interaction with the partner countries from the Ukrainian side were the Cabinet of Ministers of Ukraine,

\footnotetext{
13 Протокол про внесення змін і доповнень до Угоді про співробітніцтво у галузі трудовой міграції та соціального захисту трудових мігрантів від 15 квітня 1994 року, від 25 листопада 2005 p. (Protokol pro vnesennia zmin i dopovnen do Uhody pro spivrobitnytstvo $\vee$ haluzi trudovoi mihratsii ta sotsialnoho zakhystu trudovykh-mihrantiv vid 15 kvitnia 1994 roku, vid 25 lystopada 2005 r.). Retrieved from http://russia.mfa.gov.ua/ua/ukraine-ru/ legal-acts (data zvernennia: 28.08.2017)

14 Конвенція про правовий статус трудящих-мігрантів і членів їхніх сімей держав-учасниць Співдружності Незалежних Держав (Konventsiia pro pravovyi status trudiashchykh-mihrantiv chleniv yikhnikh simei derzhav-uchasnyts Spivdruzhnosti Nezalezhnykh Derzhav). Retrieved from http://zakon3.rada.gov.ua/ laws/show/997 j82 (data zvernennia: 28.08.2017)
}

the Ministry of Labor, the Ministry of Foreign Affairs and its structural units operating in the territories of the studied countries. Hosts and governments were also involved in the dialogue with the Special Migration Services and the Ministry of the Interior, which monitored the foreigners' stay in their territories. However, even after the establishment of a single specialized body, the State Migration Service of Ukraine, on December 9, 2010, control over the migration process of Ukrainians abroad was not one of the key tasks of this agency $)^{15}$. As a result, the dispersion of migration policy across multiple agencies has led to the fact that migration has not been a key issue for any of them.

Beginning in 2005, Ukrainian Embassies Protection Centers began to open at Ukrainian Embassies in Eastern Europe. The main purpose of such structures is to change approaches to the issue of protecting our citizens, namely to organize work to prevent possible negatives, to eliminate legal nihilism in the issue of employment abroad, to carry out preliminary legal outreach, and to provide legal protection to citizens Of Ukraine working abroad using all possible forms of protection of their rights and interests before the employers of the country of employment, arising from national law country of residence and international legal acts. These centers cooperate with Ukrainian consulates and embassies in securing the rights of Ukrainians in other countries, and in some places practically duplicate the work of Ukrainian consular institutions. The above facts indicate that there are positive developments in the legal protection of the rights of migrant workers and their families. However, they have not yet acquired a comprehensive character as of the end of 2013.

Laws of Ukraine "On Consumer Protection" (May 12, $1991)^{16}$, "On the State Border of Ukraine" (November 4, $1991)^{17}$.

Adoption of the Law "On Employment of the Population" on July 5, 2012 allowed citizens of Ukraine to engage in entrepreneurial activities during their temporary stay abroad. This document also contains provisions under which bureaux, agencies and other organizations may be created for employment of Ukrainian citizens during their temporary stay abroad - that is, it is aimed at forming the infrastructure of labor migration. In order to be entrepreneurial, these entities must obtain licenses from the State Employment Service. Thus, the Government of Ukraine has eliminated barriers for its citizens to pursue employment abroad, providing them with the right to travel abroad to other countries within the framework of existing international law and giving impetus to the creation of intermediary agencies that aim to promote employment abroad. In fact, it has expanded the network of countries where Ukrainian citizens are employed, as the latter have been able to travel to the "new abroad" - post-Soviet countries - which was seen as an attractive place for employment through a simplified adjustment process, labor market needs and stable economic ties.

In the context of the contribution of individual state bodies to the formation of the national regulatory framework for the regulation of migration processes, the decision of the National Security and Defense Council of Ukraine "On

\footnotetext{
15 Положення про державну міграційну службу України № 405/ 2011 від 6 квітня 2011 р. (Polozhennia pro Derzhavnu mihratsiinu sluzhbu Ukrainy № 405/2011 vid 6 kvitnia 2011 r.). Uriadovyi kurier. 2011. 27 kvitnia.

16 Закон України "Про захист прав споживачів" (Zakon Ukrainy "Pro zakhyst prav spozhyvachyv"). Retrieved from http://zakon.rada.gov.ua/go/1023-12 (data zvernennia: 28.08.2017)

17 Закон України "Про державний кордон України" (Zakon Ukrainy "Pro derzhavnyi kordon Ukrainy"). Retrieved from http://zakon0.rada.gov.ua/laws/show/1777-12 (data zvernennia: 28.08.2017)
} 
directions of state migration policy of Ukraine and urgent measures to improve its effectiveness" of June 15, 2007 deserves special attention (Rishennia RNBO Pro napriamy derzhavnoi mihratsiinoi polityky Ukrainy ta nevidkladni zakhody shchodo pidvyshchennia yii efektyvnost vid 15 chervnia 2007 r.). The purpose of this document was to:

- the desire to improve the state policy in the field of labor migration, which is realized through Ukraine's accession to international treaties, which regulate the relevant issues;

- conclusion of bilateral international agreements on employment and social protection of citizens working abroad;

- improvement of organizational principles in the field of providing mediation services in employment abroad

- prevention of illegal labor migration and human trafficking;

- protection of the rights and interests of Ukrainian citizens adopted by foreigners.

Also, on December 30, 2002, Regulation No. 241 "On Issuing a Work Permit to Foreigners and Stateless Persons" was adopted ${ }^{18}$, which provided for an extremely complicated and lengthy procedure for applying for, applying for and issuing employment permits (note that only consideration a potential employee's application formally should take up to 30 calendar days). It should be noted that the procedure for issuing a work permit did not provide any preferences for citizens of the CIS member states. Until January 2007, the scheme of employment of foreign workers in the territory of the Russian Federation was the only one for immigrants from any state (Ukrainians, like representatives of other former Soviet republics, had no special rights and did not enjoy special treatment by Russian officials). It consisted in the fact that the employer had to obtain permission to attract a foreign workforce by submitting to the territorial units of the FMS and the Federal State Service for Labor and Employment a statement and the necessary documents, including a draft employment contract. As a result, according to the legislation, the permit had to take no more than 45 days. After receiving it and paying taxes on the use of labor, the employer again had to contact the local FMS body. Now his goal was to get personal work permits for each of the employees he hires. Upon their receipt, medical certificates should be provided to each migrant, indicating that he or she did not have infectious diseases in society (Ivakhnyuk I.V. Migration policy of Russia, 2008: 81). In turn, a foreign national had the right to work only if he had a work permit and only in the territory of the subject of the Russian Federation where he was allowed temporary residence. The stay of a foreign national in Russia, with his native country supported by Moscow without a visa regime, extended for the duration of the concluded employment contract, but for no more than one year. The decision to extend the stay of a foreign national was made by a territorial body of a federal body of executive power.

Realizing the inefficiency of the methods used to combat illegal migration, and soberly assessing the effects of tens of thousands of workers leaving the shadows, the Russian authorities changed their tactics. In 2006, the migration legislation of the Russian Federation was

\footnotetext{
18 Рішення РНБО про напрями державної міграційної політики України та невідкладні заходи щодо підвищення їх ефективності від 15 червня 2007 р. (Rishennia RNBO Pro napriamy derzhavnoi mihratsiinoi polityky Ukrainy ta nevidkladni zakhody shchodo pidvyshchennia yii efektyvnost vid 15 chervnia 2007 r.) Retrieved from http://zakon3.rada.gov.ua/laws/show/n000852507 (data zvernennia: 28.08.2017)
}

supplemented by a number of legal acts aimed at simplifying the procedure of entry, registration and stay of labor migrants in the country legally. According to the official version, this was the answer to illegal migration, and in practice - helped to regulate the market of foreign labor.

\section{Conclusions}

Thus, analyzing the policy of migration legislation of these countries in the period 1991-2013 for migrants, including Ukrainian citizens, we can conclude that the Russian Federation objectively assessing the needs of the national labor market, tried to ensure the development of the country at the expense of visiting staff . It should be noted that, due to their relatively high qualifications and cultural and linguistic affinity with the Russians, Ukrainians were a desirable category for migrant workers. However, despite the real need of the Russian Federation for additional labor, the authorities tried to avoid competition in the internal labor market between newcomers and citizens of the Russian Federation.

Belarusian national legislation and a number of agreements with other countries (including Ukraine) regulate migration processes. At the same time, it is quite common for certain specific issues to be addressed. Currently, the system of legal acts in detail specifies the legal status and legal status of only persons belonging to the first and second categories. In practice, however, there are more and more cases where persons who have arrived in the country for training use this legal channel of entry, with quite different intentions. Upon arrival, they gradually dissolve in the local population, replenishing the statistics of illegal migrants. That is why the governments of both Ukraine and the Republic of Belarus need to improve the regulatory framework every year in order to respond timely and adequately to the new challenges of the migration movement between countries. The Republic of Moldova has tried to solve the radical problem of labor shortages caused, in particular, by the active travel abroad of its own citizens.

On the basis of the analyzed complex of normative acts of the migration legislation of individual countries of Eastern Europe (Ukraine, Russian Federation, Republic of Belarus, Republic of Moldova), a conclusion was drawn about their common basis in the form of documents of the Soviet period and provisions of international law. The vast majority of these states' laws are in line with the democratic traditions and principles of respect for human rights, while at the same time aiming to protect specific national interests in the migration field. However, the implementation of the adopted provisions in the practical sphere, in the conditions of certain political instability caused by objective (process of radical post-Soviet transformation of society) and subjective (internal political upheavals, concepts of individual political forces and leaders), remains problematic.

\section{REFERENCES}

Bessa Vilela, N., \& Brezovnik, B. (2018). Europe: hell or paradise? An overview of European law and case law. Journal of Comparative Politics, 11(2), 65-82.

Blakar, R. M. (1979). Pragmalinguistics. Mouton: The Hague-Paris Buzan, B., Waever, Ü., DeWilde, J. (1998). Security: A New Framework for Analysis. Boulder CO: Lynne Rienner, $241 \mathrm{p}$.

Carles-Berkowitz, I. (2015). What Does the Law Do for Gender: Migrant Women in the European Legislation. Droit Et Cultures, 69, 113-123.

Castles, S. and Miller, M. (1993). The Age of Migration: International Population Movements in the Modern World. London: Macmillan, $420 \mathrm{p}$.

Hansen, R. (1999). Citizenship, democracy and justice in the new 
Europe. Canadian Journal of Political Science-Revue Canadienne De Science Politique, 32(2), 399-400. DOI: https:// www.doi.org/10.1017/s0008423900010726

Hoerder, D. (2002). Migration and migrants in historical perspective. Permanencies and innovations. European Journal of Migration and Law, 4(1), 145-147. DOI: https://www.doi.org/10.1023/ a: 1014366301644

Ivakhnyuk, I. V. (2008). Migration policy of Russia: new initiatives. Bulletin of the Chelyabinsk State University. Series: Economics. Issue. 16: 81.

Komarova, E. V. (2019). Situation and Text: Representation of Migrants Whilst the Escalation of Refugee Crisis in Great Britain as Compared to Russia. Journal of Research in Applied Linguistics, 10, 80-91. DOI: https://www.doi.org/10.22055/ rals.2019.14677

Kozykina, N. V. (2010). Teoretiko-metodologicheskiye podkhody k izucheniyu mezhdunarodnoy migratsii: kontseptsiya "migratsionnykh sistem". Vestnik ChitGU. No 10 (67): 82 (In Russian).

Kuznetsova, I., \& Round, J. (2019). Postcolonial migrations in Russia: the racism, informality and discrimination nexus. International Journal of Sociology and Social Policy, 39(1-2), 52-67. DOI: https://www.doi.org/10.1108/ijssp-08-2018-0131

Ruz, C. (2015). The battle over the words used to describe migrants. BBC News. URL: http://www.bbc.com/news/magazine34061097

Schenk, F. B. (2001). Mental maps: the construction of geographical space in Europe from the Enlightenment to the present day. Novoe Literaturnoe Obozrenie. Issue 52: 42-61.

Shenk, F. B. (2019). Transcontinental migration gatewaysas places of modernity. Vestnik Permskogo Universiteta-Istoriya-Perm University Herald-History, 44(1), 114-128. DOI: https:// www.doi.org/10.17072/2219-3111-2019-1-114-128

Sredanovic, D., \& Stadlmair, J. (2018). Introduction: trends towards particularism in European citizenship policies. Journal of Contemporary European Studies, 26(1), 1-11. DOI: https:// www.doi.org/10.1080/14782804.2018.1436531

\section{LIST OF REFERENCES LINKS}

Bessa Vilela N., Brezovnik B. Europe: hell or paradise? An overview of European law and case law. Journal of Comparative Politics, 2018. 11(2), 65-82.

Blakar R. M. Pragmalinguistics. Mouton: The Hague-Paris, 1979.

Buzan B., Waever Ü., DeWilde J. Security: A New Framework for Analysis. Boulder CO: Lynne Rienner, 1998. 241 p.
Carles-Berkowitz I. What Does the Law Do for Gender: Migrant Women in the European Legislation. Droit Et Cultures, 2015. No $69,113-123$.

Castles S. and Miller M. The Age of Migration: International Population Movements in the Modern World. London: Macmillan, 1993. $420 \mathrm{p}$.

Hansen R. Citizenship, democracy and justice in the new Europe. Canadian Journal of Political Science-Revue Canadienne De Science Politique, 1999. No 32(2), 399-400. DOI: https:// www.doi.org/10.1017/s0008423900010726

Hoerder D. Migration and migrants in historical perspective. Permanencies and innovations. European Journal of Migration and Law. 2002. No 4(1), 145-147. DOI: https://www.doi.org/ 10.1023/a:1014366301644

Ivakhnyuk I. V. Migration policy of Russia: new initiatives. Bulletin of the Chelyabinsk State University. Series: Economics. 2008. Issue 16: 81.

Komarova E. V. Situation and Text: Representation of Migrants Whilst the Escalation of Refugee Crisis in Great Britain as Compared to Russia. Journal of Research in Applied Linguistics. 2019. No 10, 80-91. DOI: https://www.doi.org/ $10.22055 /$ rals.2019.14677

Козыкина Н. В. Теоретико-методологические подходы к изучению международной миграции: концепция "миграционных систем". Вестник ЧитГУ. 2010. № 10 (67). С. 82

Kuznetsova I., Round J. Postcolonial migrations in Russia: the racism, informality and discrimination nexus. International Journal of Sociology and Social Policy. 2019. No 39(1-2), 5267. DOI: https://www.doi.org/10.1108/ijssp-08-2018-0131

Ruz C. The battle over the words used to describe migrants. $B B C$ News. 2015. URL: http://www.bbc.com/news/magazine34061097

Schenk F. B. Mental maps: the construction of geographical space in Europe from the Enlightenment to the present day. Novoe Literaturnoe Obozrenie. 2001. Issue 52: 42-61.

Shenk F. B. Transcontinental migration gatewaysas places of modernity. Vestnik Permskogo Universiteta-Istoriya-Perm University Herald-History. 2019. 44(1), 114-128. DOI: https:// www.doi.org/10.17072/2219-3111-2019-1-114-128

Sredanovic D., \& Stadlmair J. Introduction: trends towards particularism in European citizenship policies. Journal of Contemporary European Studies, 2018. 26(1), 1-11. DOI: https:// www.doi.org/10.1080/14782804.2018.1436531

Марина Фротвейт,

Донеиький наиіональний університет імені Василя Стуса (м. Вінниия, Украйна)

e-mail:mn.kasianova@gmail.com, ORCID 0000-0002-4681-1664

\section{ФОРМУВАННЯ ТА ІМПЛЕМЕНТАЦІЯ МІГРАЦІЙНОГО ЗАКОНОДАВСТВА ГРОМАДЯН УКРАЇНИ ДО БІЛОРУСІ, МОЛДОВИ ТА РОСІї (1991-2013 рр.)}

Стаття відображає нормотворчість та законодавче регулювання міграційної сфери в регіоні, заснованої на спільній документальній базі, покладеній в основу національних законодавств досліджуваних країн - юридичних положень радянського періоду. Іншим джерелом міжнародного права стали загальні міжнародні норми, розроблені в рамках універсальних та специфічних міждержавних структур (ООН, МОМ, МОП тощо). Процес формування та вдосконалення міграційного законодавства в Республіці Білорусь, Республіці Молдова, Російській Федерації та Україні тривав протягом всього досліджуваного періоду. До його основних елементів відноситься створення нормативної бази із загальних питань, які опосередковано стосувалися проблем міграції та вирішення специфічних питань суто міграційної сфери. Його результати відповідали загальним нормам та демократичним принципам. У статті акцентується увага на міграційній концепції кожної 3 досліджуваних держав. Робиться висновок, що характер та масштаби міграційного руху українців у рамках досліджуваного регіону відзначаються специфікою відповідного міграційного простору. Вона заснована на сталих культурно-історичних зв'язках між акторами та підсилюється положенням міграційного законодавства Білорусі, Молдови, Росії та України.

Ключові слова: міграція; міграційна політика; міграційне законодавство; міграційні процеси.

(C) Maryna Frotveit

Надійшла до редакції: 20.09.2019

Прийнята до друку: 11.10.2019

СХІД № 6 (164) листопад-грудень 2019 р. 